The University of Maine

DigitalCommons@UMaine

Publications

Senator George J. Mitchell Center for Sustainability

Solutions

$1-2013$

\title{
The Ocean Economy of the United States: Measurement, Distribution, \& Trends
}

Charles S. Colgan

University of Southern Maine, ccolgan@miis.edu

Follow this and additional works at: https://digitalcommons.library.umaine.edu/ mitchellcenter_pubs

Part of the Natural Resource Economics Commons, and the Terrestrial and Aquatic Ecology Commons

\section{Repository Citation}

Colgan, Charles S., "The Ocean Economy of the United States: Measurement, Distribution, \& Trends" (2013). Publications. 116. https://digitalcommons.library.umaine.edu/mitchellcenter_pubs/116

This Article is brought to you for free and open access by DigitalCommons@UMaine. It has been accepted for inclusion in Publications by an authorized administrator of DigitalCommons@UMaine. For more information, please contact um.library.technical.services@maine.edu. 
The Ocean Economy of the United States: Measurement, Distribution, \& Trends

Charles S. Colgan*

Muskie School of Public Service, University of Southern Maine, PO Box 9300, Portland, ME 04104, USA

* Tel.: +1 207780 4008; fax: +1 2077804317.

E-mail address: colgan@maine.edu. 


\section{ABSTRACT}

Coastal managers are frequently required to consider the economic implications of their decisions, but economic data needed to support decisions is frequently lacking. This paper discusses the creation of a national data set that measures economic activity related to the oceans and Great Lakes of the U.S. Measures include employment, wages, establishments, and output. The data is derived from existing data maintained by the federal government to assure temporal and spatial consistency of measurement. The data set defines the "ocean economy” through a combination of industry and geographic location features to measure 21 separate industries in 6 sectors, at the national, state, and county levels. The data is subject to several suppression screens required to assure confidentiality of reported information. Analysis of the data for 2007 indicates that the national ocean economy of the U.S. is about $2 \%$ of U.S. employment and $1.7 \%$ of gross domestic product; it is comparable in size to other natural resource industries in the U.S. State and county level data indicate the ocean economy is largest in urban areas but is more likely to be a larger share of the economy of rural areas. The ocean economy data opens up numerous avenues for improvement in the estimation of employment and output and construction of models relating the ocean economy to changes in natural resources and to other changes in the economy. 


\section{Introduction}

The idea of coastal management as a policy framework has always contained an element of concern about the type and level of economic activity associated with use of ocean resources. The 1969 U.S. Commission on Marine Science, Engineering, and Technology (the Stratton Commission) is best remembered for its pioneering recommendations in coastal zone management, recommendations which would result three years later in the Coastal Zone Management Act. But a significant portion of the Commission's report dealt with ways to improve the utilization and economic contribution of the living and nonliving resources of the oceans and of finding new technologies to increase the oceans' contributions to the national economy.

As the idea of coastal management has evolved over the more than forty years since the Stratton Commission, the link between the oceans and the economy in the policy environment has been a tenuous one. Certainly many coastal management efforts have been motivated in large part by the desire to preserve and enhance fisheries resources, and many coastal management programs address issues such as ports and other infrastructure development. Coastal management is portrayed as essential to assuring that multiple uses of the coastal zone (Clark, 1996), but the dominant paradigm of coastal management is conflict between economic uses of resources and the preservation of those resources. When discussions of information needs for coastal management are undertaken, the focus is almost exclusively on the needs for data about the natural resources rather than the economic environment in which they are used (Cicin-Sain and Knecht, 1998). 
When consideration is given to the economic activity associated with the oceans it is most frequently in the context of demonstrating the importance of the coastal resources to the economy as a part of policy discussions about the need for, or approach to, coastal management. Numerous such studies exist covering various geographies. At the national level, the earliest studies attempted to identify the ocean's contribution to the national economy by estimating the gross domestic product derived from ocean-related economic activities (Nathan Associates, 1974; Pontecorvo, 1980). More recent studies have extended the analysis to include employment, wages and GDP (Luger, 1991; Kildow et al., 2009a). Similar studies have also been conducted at the regional level (Kildow et al., 2009b; Colgan, 1992), the state level (Kildow and C.S. Colgan, 2004; Donahue Institute, 2006; Henry and Barkley, 2002) and the local level (Street et al., 2001). Studies have been done for specific sectors of the ocean-related economy (Colgan, 2002) and even of specific establishments (Cunningham and Lott, 1994).

Studies of the ocean economy have also been conducted in a number of countries besides the U.S. Studies in Canada have been undertaken at the national level (Roger A. Stacey Consultants, 2003) and provincial levels (Gardner et al., 2005). Ocean economy estimates have also been undertaken for the United Kingdom (Pugh,2008), France (Kaladjian, 2007) and Australia (Allen Consulting Group, 2004).

Several other strands of policy analysis conducted to support coastal management have increasingly incorporated assessments of ocean-related economic activity. One strand arises from the incorporation of sustainability as an organizing framework for coastal management. One of the most common definitions of sustainability envisions the concept as the intersection in a Venn 
diagram between the environment, society and economy. Efforts to place activities in this ideal space are judged through indicator series capable of capturing the multiple dimensions inherent in the three dimensions describing sustainability (Bowen, 2003; Malone et al., 2010; Morrissey and O’Donoghue, 2012).

A related concept increasingly applied to coastal management is resilience, an attribute of sustainability particularly in coastal areas where the problem of natural hazards has historically been a major concern and one already increasing because of climate change (Beatley, 2009). Economic studies have examined both the levels of economic activity at risk from coastal flooding (Colgan and Merrill, 2009) and the economic damages of storm events (Colgan and Adkins, 2006).

There is thus a growing need for data on the economic activity associated with the use of ocean resources for a variety of applications in planning and policy analysis. But the wide variety of studies that have been undertaken points to a critical issue: how to measure economic activity related to the oceans in a sufficiently clear and consistent way that the results of studies can be meaningfully compared over time and across space at local, regional, and national economic levels. This paper presents the methodology for developing a data series on economic activity related to the ocean economy in the U.S., which is now available for widespread use by coastal managers and researchers.

The paper proceeds by first discussing the theoretical under-pinning of measuring the ocean economy, distinguishing between economic values and economic activity. In Section 3, the data 
foundations of the ocean economy data series are discussed, including sources and the special issues of confidentiality in the use of public data sources. Section 4 provides an overview of the U.S. ocean economy at the national, state and local (county) levels. Section 5 addresses limitations in the data set and identifies areas for further development of the data series.

\section{Conceptual foundations of ocean economy measurement}

A fundamental question underlying any management decision is whether "we" (whatever reference group is chosen) are better off taking (or not taking) some action, and of the alternatives available to "us", which leaves us "best" off. Economics provides a theoretically and methodologically consistent approach to answering these questions in general (CBA) and addresses specifically how the values of natural resources such as those associated with the ocean may be addressed ${ }^{1}$ (NOEP EPA).

Using these approaches is a key to management because the resources (money, time, people) to address ocean and coastal issues are themselves scarce and must be used carefully. Unfortunately, the optimal approach to answering these questions has two major limitations: it is time consuming and expensive to collect the data and the answers provided require careful explanation for noneconomist decision makers and publics.

The approach detailed in this paper offers another way to think about the economic consequences of alternative management strategies, one which attempts the answer the question "how does the economic activity associated with ocean change” rather than "are we better or worse off?” The 
question of economic activity is conceptually inferior because economic activity in some areas may increase even though society is not better off (a large increase in employment in coastal construction to offset the effects of sea level rise and storm damages). But it does address issues of high salience to decision makers and the public and can be undertaken with data that is much more readily available across time and space than other economic information.

The ocean economy as the term is used here is thus a measure of economic activity rather than economic value. Activity is measured through four concepts:

- Establishments. An employment establishment is a place where employees work. It is not the same thing as an employer, because an employer can have many establishments.

- Employment. Employment is actually a complex phenomenon. Employment can be full or part time, full or part year. Employment can be the result of hiring decisions by an organization and or it can be self-employment. The levels of employment change on a daily basis as people are hired, fired, retired, and voluntarily leave. For purposes of the measurement of the ocean economy, self-employment is excluded and employees are reported on a monthly basis. More detail is provided in Section 3 on data sources.

- Wages. Wages are the total wages and salaries paid to employees; wages do not include benefits such as health insurance.

- Gross Domestic Product-State. The gross domestic product (GDP) is the market value of goods and services produced in the economy. At the national level, GDP is measured at the point of final purchase by consumers, the government, investors, or exports to other countries. But the ocean economy derives from a subset of the national economy defined 
by both what is produced and where it is produced. For this purpose the question is not what is the market value at the final point of sale (which could be anywhere) but what is the value of the output of specific products related to the ocean.

This requires the use of a value added form of GDP which measures the output of industries defined as part of the ocean economy as the net value of their output - the total value of their sales less the value of inputs purchased to make that final value, or the valued added of each industry. The appropriate measure in the U.S. is called the Gross Domestic Product-State.

For more information see (Bureau of Economic Analysis, 2006)

$$
\mathrm{GDP}-\mathrm{S}_{\mathrm{S}}=\mathrm{CP}_{\mathrm{S}}+T_{\mathrm{S}}+\mathrm{NOS}_{\mathrm{S}}
$$

where: GDP-S $\mathrm{s}_{\mathrm{s}}$ GDP-State for state $\mathrm{s} ; \mathrm{CP}_{\mathrm{s}}=$ Compensation of employees in state $\mathrm{s} ; T_{\mathrm{s}}=$ Taxes on production in state $\mathrm{s} ; \mathrm{NOS}_{\mathrm{s}}=$ Net operating surplus of State $\mathrm{s}$.

The measurement of the value of output requires adjustments for price changes; if GDP-S changes simply because prices go up (or down) between any two time periods, it is not possible to determine the real change in output. Thus a means to hold price changes constant is required. The most common way to do this is with a price index, such as the well-known consumer price index. However the GDP-S data uses a chain-weighted index, which incorporates changes over more than one period. The chain-weighted index is the standard adjustment for all GDP data. 
3. Data sources and estimation

The estimation of data for measuring ocean economic activity should have several characteristics:

1. Data should be continually measured, that is it should be capable of tracking trends across time.

2. It should be consistently measured in all coastal areas, assuring that activity measured in one place can be compared with other locations.

3. The measurement of the ocean economy should be consistent with the measurement of economic activity in other sectors so that comparisons are possible.

4. The data should be capable of distinguishing among different industries associated with the ocean and it should be aggregated at national, state, regional and local levels.

This implies that the derivation of ocean economy estimates should be undertaken by adapting existing data to the purpose. Two major federal data sets are used to construct the ocean economy data series: the Quarterly Census of Employment and Wages (QCEW) administered by the Bureau of Labor Statistics (BLS) in the Department of Labor, and Gross Domestic ProductState (GDP-S) data prepared by the Bureau of Economic Analysis (BEA) in the Department of Commerce.

The QCEW contains the employment, establishment, and wage data. It is collected initially by state departments of labor and all data is provided to the BLS in Washington. QCEW data is 
collected quarterly; all employers covered by the appropriate federal laws report the employment for each month and total wages paid over the entire quarter. The QCEW covers about $85 \%$ of all employment in the U.S. Employment is reported irrespective of hours worked. Employment is also reported without regard to the people holding the jobs (individuals can hold more than one job). Employment is reported at the place of employment rather than the place of residence.

For purposes of estimating the ocean economy, a selection of QCEW data is made based on two criteria:

- Production of goods or services where ocean and marine resources are an input or where the good or service will be used primarily or exclusively in the marine setting.

- The geographic location of the economic activity implies a relationship with the ocean.

Thus the ocean economy definition derives from both an industrial and a geographic component. Some industries, such as fisheries harvesting and processing, are included in the ocean economy regardless of location. Others, including those in tourism and recreation, are included only when located in a specific geography. ${ }^{2}$

Table 1 shows the sectors and industries defined for the ocean economy. There are 23 ocean economy industries made up of 48 individual industries defined by the North American Industrial Classification System (NAICS). The 26 ocean industries are grouped in 6 sectors. The aggregation of NAICS-defined industries into ocean industries avoids suppression of data for confidentiality purposes (discussed in greater detail below). 
Data from the QCEW is selected for each industry depending on its location:

- State - location anywhere in a coastal state

- Coastal county - location anywhere in a county covered by a state-defined Coastal Zone Management Program

- Shore-adjacent zip code - location in a zip (postal) code adjacent to the ocean, major embayment, or Great Lake.

The selection of geographies for the ocean economy presents a number of challenging issues leading to some inherently arbitrary decisions about what to include and what to exclude. Zip codes can be used with the addresses of establishments to define locations closer to the shoreline than the larger county boundaries that are the basic geography of most U.S. regional data. Both counties and zip codes vary in size tremendously across the 30 coastal states, but in general zip codes provide a small geography useful for analysis since it is coded on the physical address field of all establishment records. It is particularly useful in large population counties or cities where zip codes tend to be very small in area because of density and thus can effectively distinguish locations close to the shoreline.

Shoreline is also a complex concept. The concept of shore adjacency is used to define the entire tourism \& recreation sector and is also used to define the counties where other ocean industries are measured. For purposes of defining the shoreline for the ocean economy, the GIS layer defining the shoreline for the federal Coastal Zone Management Program is used to intersect with county and zip code boundary layers. The shoreline of interest is that adjacent to the oceans, 
Great Lakes, and major embayments (e.g. Chesapeake Bay, San Francisco Bay and Puget Sound).

Another critical issue in the selection of geographies is how far up major rivers the concept of ocean shoreline should extend. The Coastal Zone Management Program includes substantial portions of riverine shoreline so with river shorelines some arbitrary decisions were made some of involved shortening the river portions of the coastal zone and some lengthening the river portion.

The concept of shore adjacency applies at two levels: to counties and, for the tourism \& recreation sector, at the zip code level. For some industries, such as those in the minerals sector and warehousing in the transportation sector, the geography is the coastal (zone) county. The majority of the ocean economy is found in counties that contain shore-adjacent zip codes, though there are some variations.

In the selection of industries to include, some are obvious choices such as marine fishing or marine freight and passenger transportation and data for these industries are selected wherever they are located in a coastal state. Others, such as hotels and restaurants or marinas, are most likely to be associated with ocean-related economic activity when they are proximate to the shore, which is the purpose of the shore-adjacent zip code criterion.

A third group of industries may serve the ocean economy and other parts of the economy regardless of location. For industries such as oil and gas exploration and production or in 
warehousing, the locational factor is highly ambiguous. Oil and gas establishments operating or supporting operations on the continental shelf will most likely be located near the shore but may also serve onshore operations. Warehousing connected with port operations has historically been located adjacent to piers, but the containerization revolution plus the huge growth in marine freight traffic has meant warehousing has shifted well inland in places like Los Angeles. The warehousing industry's and minerals sector's inclusion in the ocean economy based on location in a shore-adjacent county (rather than a shore-adjacent zip code) is a compromise reflecting the ambiguity inherent in these industries.

The industries identified in Table 1 are applied to the QCEW data to derive the estimates of establishment, employment, and wages. This required accessing QCEW in two different ways: at the establishment level for firms in tourism \& recreation where the zip code data is available and at the industry level for other sectors/industries. The establishment data is confidential and is accessed by special permission at the Bureau of Labor Statistics in Washington. The published aggregate industry data made available for all counties by the BLS (www.bls.gov) is used for county-wide data. Each of these portals into the QCEW raises issues about the suppression of data for confidentiality; these issues are discussed below in Section 4 .

Once the data from the QCEW is extracted, GDP-S estimates are made. The Bureau of Economic Analysis publishes GDP-S data at the state and metropolitan area levels only. Special calculations are required to match the QCEW data with the BEA GDP-S data by disaggregating the published GDP-S data to the appropriate industry and geographic level. This can be done by computing each industry or establishment's share of state GDP-S based on the share of wages 
paid. Eq. (2) shows this calculation as applied to the establishment level QCEW data; the calculation for industry level data follows the same principle.

4. Special issues in using public data: confidentiality

Public economic data series must generally conform to rules concerning confidentiality, meaning that no data can be published from which it would be possible to determine the employment or wages of a single establishment. This means that the finer the detail in either industry or geography the more likely that data must be suppressed to protect confidentiality. When, as in the case of the ocean economy data, the needs are for fine grain industrial and geographic detail, the needs for suppressions will be high. In addition, special care must be taken with the use of confidential establishment data to maintain the same standards of confidentiality found in the data released by government agencies.

The screening process for confidentiality involves a three-stage process: (1) primary screening which detects those instances where disclosure has a high probability of revealing a single establishment; (2) secondary screening, in which for any grouping of industries where a total is shown, if one industry is suppressed then another must be suppressed to prevent calculation of the suppressed primary values; and (3) complementary suppression which requires comparison of data from the establishment series with the published data to prevent any totals from the confidential establishment data permitting secondary disclosure in the published data. 
Primary suppression is accomplished through the application of rules that test for the number of establishments and the proportion of employment in the largest establishments for a given industry/geography combination. The principle is that the data should not be disclosed if the number of establishments is small or only few establishments account for most of the employment. The primary suppression test for this data was the "p-percent" rule which provides confidentiality protection in cases where there are two very large establishments in the cell.

The interaction of these tests can best be explained with an example, provided in Table 2. In Table 2, hypothetical data for the transportation sector and industries at the state level are shown in four panels: the top two panels show actual data from the establishment level data; on the left are the actual data, while on the right the reorganization of the data for the NAICS industry into the industries in the ocean economy transportation sector. The bottom panels show the data that is published by BLS in its public version of the QCEW on the left and on the right the data that would be published in the ocean economy data set.

In the Freight Transportation industry one NAICS industry (Coastal and Great Lakes Freight Transportation) has only 2 establishments. This would require the suppression of the employment for this industry. Because one of the two industries in this ocean economy industry is suppressed the total of the two industries must be suppressed (secondary suppression). Among the industries making up the ocean economy industry marine transportation services one, port and harbor operations, is not disclosed. Because it would be possible to calculate this one industry by subtracting the published values for the other industries from the ocean economy total, this industry is also suppressed in the ocean economy (complementary suppression). In the 
ocean economy data, two industries are suppressed so no additional suppressions are needed. If only one industry had been suppressed because of primary and secondary suppressions, a second ocean economy industry would have been suppressed.

Data suppressions are common throughout public economic data, particularly in small geographies. To overcome some of the limitations, totals for higher geographic and industry levels should be calculated from original establishment data in order to be as complete as possible. This strategy is employed throughout the ocean economy data where state, and national totals for the ocean economy and the major sectors are derived from establishment level data. At the county level, only sectoral totals are shown and these are subject to the suppression rules. The ocean economy total at the county level is also derived from the establishment data to provide the most accurate totals. ${ }^{3}$

\section{The U.S. ocean economy}

The development of a data series on the ocean economy offers numerous possibilities for dimensionalizing economic activity related to the use of ocean resources. This section discusses the size of that economy in the U.S. and notes some recent trends. It also demonstrates how the data at the state and local (county) level can be used.

Table 3 presents the data for the U.S. ocean economy in 2007. That year is chosen because it was the last year before the recession set in and which altered the patterns significantly (these effects are discussed below). The total size of the ocean economy is 2.68 million employees working in 
over 140,000 establishments and earning nearly \$94 billion in wages. In 2007, these industries contributed over $\$ 238$ billion to the U.S. GDP. The largest sector by employment is tourism and recreation with eating \& drinking places located in shore-adjacent zip codes the largest industry employment. The largest sector in contribution to GDP is minerals with oil and gas exploration and production the largest industry by GDP. The largest sectors and industries reflect one of the most important characteristics of the ocean economy: it is dominated in employment by service industries (tourism \& recreation plus transportation, which account for $83 \%$ of employment) but in GDP it is dominated in output by goods-related industries (construction, minerals, living resources, ship \& boat building); these industries comprise $58 \%$ of the ocean economy output.

The ocean economy comprised $1.99 \%$ of total wage \& salary employment in 2007 , and about $1.6 \%$ of establishments and wages. It comprised $1.7 \%$ of U.S. GDP. These proportions seem small, but they reflect how large the U.S. economy actually is, with 143 million employees in 2007 and \$14 trillion in output. To get perspective on size, it helps to compare the ocean economy to other sectors as is done in Table 4, which provides employment and GDP figures for other natural resource industries in the U.S. The ocean economy is larger than agriculture, forest products, and mining employment, and is considerably larger than forest products in GDP. Food production as a whole is larger than the ocean industry, though the ocean economy is nearly half again as large as primary agriculture. The metals, minerals, and energy sector is larger than the ocean economy, although of course the ocean economy minerals sector comprises a major portion of this natural resource sector. 
The ocean economy tends to parallel the direction of the national economy within the business cycle, expanding during growth periods and contracting during recessions. But there is considerable variance in short-term economic performance between the ocean economy and the national economy because key sectors in the ocean economy are relatively volatile on a shortterm basis (Table 5).

Overall, the ocean economy grew somewhat faster in 2005-07 and declined somewhat less than the U.S. economy as a whole in 2007-09 in terms of employment. The ocean economy clearly outperformed the national economy in terms of GDP growth.

During the last years of the national expansion of the 2000's all ocean sectors grew in employment, except Living Resources, which has been suffering a long-term decline in employment because reductions in fish harvesting and processing. During the first two years of the recession, all ocean economy sectors lost employment, but two sectors showed significant gains in real GDP. One was in marine construction, which is a very volatile sector in which large projects can sway even national figures; the early funding of the American Recovery and Reinvestment Act and its emphasis on moving funds quickly into construction projects in 2009 influenced this sector. The other large GDP gain was in minerals. The gains in these two sectors drove overall real GDP for the ocean economy growth in these two years even as the national economy was shrinking.

The reason for the large gain in real GDP in the minerals sector was the sharp fall in oil prices in late 2008 and early 2009 following the record price increase in early 2008. A rise in prices 
results in a fall in real GDP (the value of a barrel of oil increases solely because of price change) and the opposite occurs if prices fall - the real value increases because the same barrel of oil costs less. Leaving the volatile minerals and construction sectors out, the ocean economy still declined 0.5\% between 2007 and 2009, a figure which was still somewhat better performance than the national economy.

The state level ocean economies are examined in Table 6, which ranks the states on various measures. In general, whether ranked by employment or GDP, the larger, more urban coastal states have the larger ocean economies, though the ranking among the top 5 changes with the measurement of employment vs. output. California ranks first in employment, but the large role of minerals in the ocean GDP pushes Texas into first place on that ranking. The same force pushes Louisiana from ninth on employment to third on GDP. Florida ranks in the top five on both, as does Hawaii in the top ten primarily on the basis of tourism \& recreation.

Another perspective on the relative size of the ocean economies of the states is provided by considering the size of the ocean economy normalized by shoreline length, which is a measure of the concentration of economic activity in the coastal area. The employment and GDP per kilometer of shoreline $e^{4}$ are shown in Table 7.

On a per kilometer of shoreline basis, the advantage goes to the states with urban areas in smaller coastlines, with Illinois at the top of both lists. The larger states like Texas, New York, and California are still near the top, but smaller states, such as Mississippi and Connecticut with large ship building industries move up the rankings considerably. North and South Carolina also 
illustrate concentration of economic activity along the shore. Both states rank near the middle of the coastal states in size, and South Carolina maintains this ranking on a length-normalized basis, but North Carolina falls nearer the bottom of the rankings because the geography of its shoreline is dominated by the barrier islands and sounds which are relatively devoid of economic activity.

The concentration of the ocean economy within the overall state economies provides another way to look at the ocean economy. The appropriate measure for this is the specialization ratio, also knows as the location quotient, which is calculated as the ratio of concentration of an industry or sector in a selected geography to the same concentration in a reference geography.

$\sum_{x 3-n} \geq \mathrm{p} / 100 x_{1}$

$\frac{\frac{e_{s}^{i}}{e_{s}^{t}}}{\frac{E_{n}^{i}}{E_{n}^{t}}}$

where: $e_{s}^{i}$ employment in industry $i$ in state $s ; e_{s}^{t}=$ total employment in state $s ; E_{n}^{i}=$ employment in industry $i$ in the nation; $E_{s}^{t}=$ total employment in the nation.

For purposes of calculating the specialization ratio in this analysis, the nation is defined as the 30 coastal states rather than the U.S. as a whole. In theory, the specialization ratio reflects the level of specialization in an economy where firms are free to locate anywhere, and thus reflects the competitive advantage of the regional (state) economies. Since industries such as marine fisheries and ports cannot locate in inland states, the use of the national totals would be inappropriate. 
Table 8 shows the top 5 states by specialization for the ocean economy as a whole and for each of the six major sectors. The top four states in ocean economy specialization are all characterized by having most of their economies in coastal areas. Hawaii, not surprisingly, has the highest specialization in both the tourism \& recreation sector and in the ocean economy as a whole. Maine also uses a high specialization in tourism \& recreation plus ship \& boat building and living resources to achieve a high ranking in ocean economy specialization. The most specialized states in transportation may seem somewhat surprising, but this reflects the relative proportionality of a sector rather than its absolute proportionality.

Specialization in ship \& boat building requires a special note. Ship building in the United States is primarily the construction and repair of naval ships and there are a relatively small number of locations where this is done, including Virginia, Maine, Mississippi, and Connecticut. In the case of the first three states, there are sufficient numbers of ship and boat building establishments that suppression of data for confidentiality at the state level is not necessary, but this is not the case for Connecticut where a single firm (the Electric Boat Division of General Dynamics in Groton) dominates this sector. Connecticut thus does not appear on this list and is replaced by Louisiana and Rhode Island.

Table 9 provides a brief overview of ocean economy data at the county level, ranking the top 5 counties by employment size and employment specialization in 2007 for the ocean economy and for each of the six sectors. Rankings by size produces expected results in terms of the overall ocean economy with the major cities ranked highest. But by specialization, it is much smaller 
counties in Alaska ${ }^{5}$ and in the Upper Peninsula of Michigan, along with the Gulf Coast County of Jackson, Mississippi that show the highest specialization in the ocean economy.

This pattern of the ocean economy being a more important element in the economy in smaller, more rural areas even though larger urban areas have the largest absolute size of ocean economy sectors is demonstrated by the data for ocean economy as a whole, for living resources, minerals, tourism \& recreation, and transportation. The ocean economy is larger in urban areas, but more important to the local economy in rural areas.

6. Data limitations and future development

The ocean economy data described here reflects a tradeoff between comparability and precision. The choice to adapt existing economic data series to a measurement of the ocean's and Great Lakes contribution to generating economic activity means that it possible to have data across the entire country and at various geographic levels and to permit inter-temporal measurement of change and comparison to other types of economic activity makes possible a variety of insights in the nature of the relationship between the oceans and Great Lakes and the larger economy.

But these insights are incomplete because of the gaps in the data that are used. The data series both under-estimates some sectors and over-estimates others; the net effect of these errors is unknown. Among the under-estimates are: 
- The lack of data for the fisheries harvesting industry. Fisheries harvesters are, in all but a few cases, not considered to be employees but are self-employed. As self-employed workers, most harvesters are not reported in the employment data series.

- Annual average data is used for these estimates to assure comparability with other data sets including GDP. But the ocean economy, particularly in the tourism \& recreation sector, is highly seasonal.

The over-estimates are primarily in the tourism \& recreation sector. Not every employee in a restaurant in Manhattan (New York County, NY) or hotel is employed because of tourists wishing to take advantage of ocean-related tourism like the U.S. Intrepid museum. To correctly identify that portion of these industries that is tied to the ocean would require detailed expenditure data on tourists and recreationists so as to calculate the share of expenditures associated with the ocean. It would be necessary to know how much tourists spent on a Broadway show vs. the Intrepid museum. Eating establishments also serve local residents for non-recreational purposes and separating these uses would require additional detailed expenditure analysis of residents.

Another source of overestimation is in the Gross Domestic Product-State data. There are several hundred industrial taxonomy codes in the North American Industrial Classification System but GDP data is released only for 56 detailed industries (and 25 aggregated sectors). While there are detailed GDP data for the manufacturing sectors, other sectors are highly aggregate; for example, the entire retail sector is covered by one GDP-code. 
These limitations on the data point to two basic directions for future research in this area. First, efforts should be made to improve the estimates derived from the national data series. This includes working with the states that do not permit access to the national database for these purposes to produce estimates from their own data. It also involves investigating what refinements in the estimation of GDP may be useful. The Bureau of Economic Analysis has undertaken special estimates of GDP in the form of satellite accounts for sectors not described in adequate detail in the published data.

Further development of the national data series also should include the addition of new industries. At the top of this list would be the fisheries harvesting industry. Employment in this industry is periodically estimated for regulatory impact analysis purposes, but such studies have not been regular enough to build a consistent data set from. A state-federal cooperative program could use permitting and landings report data to create a more consistent measurement of fisheries employment if funding were available. The non-employer data series of the Census Bureau, which attempts to estimate self-employment may provide another source of fisheries harvesting. The real estate sales sector in shoreline communities would be another industry where self-employment restricts the measurement of an economic activity that, in the appropriate location, is heavily ocean dependent.

Beyond these existing sectors, there is an emerging industry in renewable energy production in the marine environment, including wind and tidal power. These industries are likely to grow significantly over the next decade, and at the moment there is no NAICS code that adequately 
covers either their construction or operation (these may be included in the 2012 revisions to NAICS).

The other major approach to improving these estimates will be at the local level. Those doing studies of the ocean economy at the state or local level are at liberty to extend and refine the estimates in the national data. For example, marine science has been specifically included in studies of the California ocean economy (Kildow and Colgan, 2004). Data missing because of suppression, as in the ship building industry, can usually be added by contacting the firms involved. Such firms are usually willing to reveal employment data (though rarely wages). In these circumstances, the national data series is a starting point rather than an ending point.

The preceding discussion has focused on research needs to improve the estimation of the ocean economy, but the availability of this data opens up the opportunity to construct new models of the economics of ocean resources. One set of models could link the ocean economy more systematically to trends in the national and regional economies so that changes in ocean-related economic activity could be separated into those influenced by management decisions and those influenced by larger national or regional economic trends.

This data is also critical to the development of coupled human and natural systems models in which human systems were represented by ocean economic activity (Liu et al., 2007). Such models may be particularly valuable in support of the increasing attention to marine spatial planning (Douvere, 2008). The ocean economy data series would provide a critical link between 
the measurement of onshore socio-economic activities affecting the spatial area for which planning is undertaken and human uses of the oceans.

Linking changes in the economic system to changes in natural systems is ultimately the most important use for this data, but it is also the hardest because of differing time and spatial scales in the functioning of the different systems, and also because the data needs for even partially complete versions of such coupled models are often enormous. The creation of a time series on ocean economic activity available at relatively small geographic scales is an important start to the construction of such models, but still just a start.

\section{Conclusions}

The data series described in this paper are available for public use from two sources. The Coastal Services Center of the National Oceanic and Atmospheric Administration has made the data available through its Economy-National Ocean Watch (E-NOW) (http://www.csc.noaa.gov/digitalcoast/data/enow/index.html). The data is also available from the National Ocean Economics Program (NOEP) at www.oceaneconomics.org. Users can select the data and the types of displays and downloads that they find most useful to their purposes. NOAA has also entered into an agreement with the Bureau of Labor Statistics to shift the production of the data from the author, who has been responsible for development of the data and associated programming, to NOAA in order to update the data regularly, incorporating the most recent employment and GDP data. 
As a regular data series of the federal government, the ocean economy data offers opportunities to better understand the human dimensions of interactions with the oceans and Great Lakes and to better communicate that understanding to a wide community of coastal managers and researchers. The data series as currently constructed needs continuous improvement and expansion to better reflect the realities of a complex and dynamic economic system coupled to equally complex and dynamic marine ecosystems.

Measurements of economic activity associated with the oceans are an evolving field of research in support of coastal and ocean management actions. Like all measures they are imperfect and can help answer one set of important questions but not all. This will be most useful in helping understand how the economies of places that depend on the oceans are changing and may change as a result of management decisions or larger socio-economic forces, information which is often the most commonly asked economic question about ocean management decisions in policy debates. 
References

Allen Consulting Group, 2004. The Economic Contribution of Australia’s Marine Industries 1995-95 to 2002-03. The National Oceans Office, Canberra.

Beatley, Timothy, 2009. Planning for Coastal Resilience. Island Press, Washington DC.

Bowen, R., 2003. Socio-economic indicators and integrated coastal management. Ocean \& Coastal Management 46 (3-4), 299-312.

Bureau of Economic Analysis, 2006. Gross Domestic Product by State: Estimation Methodology. Washington DC. www.bea.gov.

Cicin-Sain, Biliana, Knecht, Robert W., 1998. Integrated Coastal and Ocean Management: Concepts and Practices. Island Press, Washington DC.

Clark, John R., 1996. Coastal Zone Management Handbook. CRC Publishing, Boca Raton, FL. Colgan, C.S., Adkins, J., November 2006. Hurricane Damage to the U.S. Ocean Economy in 2005. Monthly Labor Review.

Colgan, C., Merrill, S., 2009. The effects of climate change on economic activity in Maine: coastal York county case study. Maine Policy Review 17 (2), 67-79.

Colgan, C., 1992. Economic growth trends in the Gulf of Maine Littoral. In: Townsend, David (Ed.), The Gulf of Maine as an Estuarine System. NOAA Office of Estuarine Programs, Washington DC.

Colgan, C., 2002. A Profile of Marine Trades in Maine. Maine Center for Business \& Economic Research, Portland, ME.

Cunningham, Steven R., Lott, William F., 1994. Mystic Seaport: Economic Contributions from Continuing Operations. Connecticut Center for Economic Analysis, Storrs, CT. 
Donahue Institute, 2006. An Assessment of the Coastal and Marine Economies of Massachusetts Report 1. University of Massachusetts, Amherst, MA.

Douvere, Fanny, 2008. The importance of marine spatial planning in advancing ecosystem-based sea use management. Marine Policy 32 (5), 762-771.

Gardner, M., et al., 2005. Economic Value of the Nova Scotia Ocean Sector. Nova Scotia Department of Economic Development, Halifax, NS.

Henry, Mark S., Barkley, David L., 2002. The Contribution of the Coast to the South Carolina Economy: Agriculture. Clemson University Regional Economic Development Laboratory, Clemson, SC.

Kaladjian, R., 2007. La mer a de l’avenir: Données économiques maritimes françaises 2007. Institut français pour l'exploitation de la mer, Issy-les-Moulineaux, France.

Kildow, J.T., Colgan, C.S., 2004. The California Ocean Economy 1990e2000. Agency for Natural Resources, Sacramento, CA.

Kildow, J.T., Colgan, C., Scorse, J., 2009a. State of the U.S. Ocean and Coastal Economies 2009. National Ocean Economics Program, Monterey, CA.

Kildow, J.T., Colgan, C., Pendleton, L., 2009b. The changing ocean and coastal economies of the United States Gulf of Mexico. In: James, Cato (Ed.), The Gulf of Mexico: Origins, Waters, and Biota. Texas A\&M University Press, College Station, Texas.

Liu, J., et al., 2007. Complexity of coupled human and natural systems. Science 317 (5844), 1513-1516.

Luger, M., 1991. The economic value of the coastal zone. Environmental Systems 21 (4), 278301. 
Malone, T., et al., 2010. Climate change, sustainable development and coastal ocean information needs. Procedia Environmental Sciences 1, 324-341.

Morrissey, Karyn, O’Donoghue, Cathal, March 2012. The Irish marine economy and regional development. Marine Policy 36 (2), 358-364.

Nathan Associates, 1974. Gross Product Originating from Ocean-related Activities. U.S. Department of Commerce, Washington DC.

Pontecorvo, 1980. Contribution of the ocean sector to the U.S. economy. Science 208, 10001006.

Pugh, D., 2008. Socio-economic Indicators of Marine-related Activities in the UK. The Crown Estate, London.

Roger A. Stacey Consultants, 2003. Canada’s Ocean Industries: Contribution to the Economy 1988-2000. Fisheries \& Oceans Canada, Ottawa.

StreetSouth HighWest Chester, 2001. Final Report: An Assessment of the Economic Value of the Coastal Bays' Natural Resources to the Economy of Worcester County. Maryland, Annapolis, MD. 
Footnotes

${ }^{1}$ Extensive bibliographic resources for studies of this type can be found at the websites of the National Ocean Economics Program www.oceaneconomics.org and of the National Center for Environmental Economics http://yosemite.epa.gov/ee/epa/eed.nsf/webpages/homepage

${ }^{2}$ Because development of the ocean economy data has been funded by primarily by the National Oceanic and Atmospheric Administration, a decision was made early in the development phase to include the Great Lakes states in the ocean economy because the Coastal Zone Management Act includes these states. The term ocean and Great Lakes economy is thus a more accurate, though somewhat wordier term. For the sake of brevity, the term ocean economy is used, with the Great Lakes implicitly incorporated.

3 The problem of confidentiality protection has one additional application in the ocean economy. The QCEW data is collected through a joint federal-state program in which state departments of labor perform the primary data collection. These state agencies operate with federal funding but under state law and access to the data for purposes such as the construction of ocean economy requires the permission of state agencies. Four states (Massachusetts, Michigan, New Hampshire, and New York) did not grant permission for the use of their data; all of the other coastal states did grant permission. For these four states access to the establishment data for calculating all of the ocean economy is not possible so the public data is used. This results in two issues for the data in these states: First, the totals for the industries and sectors will reflect suppressed data in the public data series and thus be less accurate than the data derived from the 
establishment data. Second, some way must be found to approximate the shore-adjacent zip code data for the tourism \& recreation sector. For these four states the effects of shore adjacency are approximated using the Census Zip Code Business Pattern data. Zip Code Business Patterns is a data series from the Census that is based on the number of the number of establishments in an industry in a given zip code by employment size. A zip code adjustment factor is calculated as: $Z_{i}^{c}=\sum_{i=1}^{n} M_{1}^{i} \ldots M_{10}^{i} / \sum_{i=1}^{n} M_{1}^{t} \ldots M_{10}^{t}$ where $Z_{i}^{c}$ : The adjustment factor for industry $i$ in county C. $M_{1-10}^{i}$ : The mean of the employment range reported for industry $i$ in a shore-adjacent zip code in Zip Code Business Patterns. For example, the mean of the employment range 1-5 is taken as 3, the mean of the employment range 7-10 is taken as 7, etc. This creates a pseudo employment total for the industry in the zip code. $M_{1-10}^{c}$ : The mean of the employment range as above for the sum of all zip codes in the county. The zip code adjustment factor thus represents the approximate proportion of a given tourism \& recreation industry in a county that is located in the shore-adjacent zip codes; where a county is comprised of all shore-adjacent zip codes the adjustment factor has a value of 1 . The adjustment factor is multiplied by the wage and employment data from the QCEW to derive the final estimates for those four states.

${ }^{4}$ Shoreline length is calculated as a linear approximation using GIS files from the Census. Fine scale shoreline data are available from NOAA, but these representations overstate the geography available for economic activity by tracing the length of the complex flows of estuaries in states such as Louisiana and South Carolina.

${ }^{5}$ In Alaska counties do not exist. Data is collected for the borough or, where no substantive local government exists, Census Designated Area. 
Table 1

Ocean economy industries and geography

\begin{tabular}{|c|c|c|c|c|}
\hline \multicolumn{5}{|c|}{ Ocean economy sectors and industries by NAICS codes and geographic definition } \\
\hline Ocean economy sector & Ocean economy industry & NAICS code & NAICS industry (2007 NAICS) & Geography \\
\hline Construction & Marine construction & 237990 & Other heavy and civil engineering construction & Coastal county \\
\hline \multirow{8}{*}{ Living resources } & \multirow[t]{2}{*}{ Fish hatcheries $\&$ aquaculture } & 112511 & Finfish farming and fish hatcheries & \multirow[t]{8}{*}{ State } \\
\hline & & 112512 & Shellfish farming & \\
\hline & \multirow[t]{3}{*}{ Fishing } & 114111 & Finfish fishing & \\
\hline & & 114112 & Shellfish fishing & \\
\hline & & 114119 & Other marine fishing & \\
\hline & \multirow[t]{2}{*}{ Seafood processing } & 311711 & Seafood Canning & \\
\hline & & 311712 & Fresh and frozen seafood processing & \\
\hline & Seafood markets & 445220 & Fish and seafood markets & \\
\hline \multirow[t]{5}{*}{ Minerals } & Sand \& gravel & 212321 & Construction sand and gravel mining & \multirow[t]{5}{*}{ Coastal county } \\
\hline & \multirow[t]{4}{*}{ Oil \& gas exploration and production } & 211111 & Crude petroleum and natural gas extraction & \\
\hline & & 213111 & Drilling oil and gas wells & \\
\hline & & 213112 & Support activates for oil and gas operations & \\
\hline & & 541360 & Geophysical exploration and mapping services & \\
\hline \multirow[t]{2}{*}{ Ship \& boat building and repair } & Boat building \& repair & 336612 & Boat building \& repair & \multirow[t]{2}{*}{ State } \\
\hline & Ship building \& repair & 336611 & Ship building \& repair & \\
\hline \multirow{17}{*}{ Tourism \& recreation } & Boat dealers & 441222 & Boat dealers & \multirow{17}{*}{$\begin{array}{l}\text { Shore-adjacent } \\
\text { zip code }\end{array}$} \\
\hline & \multirow[t]{4}{*}{ Eating $\&$ drinking places } & 722110 & Full service restaurants & \\
\hline & & 722211 & Limited service eating places & \\
\hline & & 722212 & Cafeterias & \\
\hline & & 722213 & Snack and nonalcoholic beverage bars & \\
\hline & \multirow[t]{2}{*}{ Hotels \& lodging places } & 721110 & Hotels (except Casino hotels) and motels & \\
\hline & & 721191 & Bed and breakfast inns & \\
\hline & Marinas & 713930 & Marinas & \\
\hline & Recreational vehicle parks \& campsites & 721211 & RV parks and recreational camps & \\
\hline & Scenic water tours & 487210 & Scenic and sightseeing transportation, water & \\
\hline & Sporting goods & 339920 & Sporting and athletic goods manufacturing & \\
\hline & \multirow{4}{*}{ Amusement \& recreation services } & 487990 & Scenic and sightseeing transportation, other & \\
\hline & & 611620 & Sports and recreation instruction & \\
\hline & & 532292 & Recreation goods rental & \\
\hline & & 713990 & Amusement and recreation services not elsewhere classified & \\
\hline & \multirow[t]{2}{*}{ Zoos, Aquaria } & 712130 & Zoos and botanical gardens & \\
\hline & & 712190 & Nature parks and other similar institutions & \\
\hline \multirow[t]{12}{*}{ Transportation } & \multirow[t]{2}{*}{ Freight transportation } & 483111 & Deep sea freight transportation & \multirow[t]{9}{*}{ State } \\
\hline & & 483113 & Coastal and great lakes freight transportation & \\
\hline & \multirow[t]{2}{*}{ Marine passenger transportation } & 483112 & Deep sea passenger transportation & \\
\hline & & 483114 & Coastal and great lakes passenger transportation & \\
\hline & \multirow[t]{4}{*}{ Marine transportation services } & 488310 & Port and harbor operations & \\
\hline & & 488320 & Marine cargo handling & \\
\hline & & 488330 & Navigational services to shipping & \\
\hline & & 488390 & Other support activities for water transportation & \\
\hline & Search and navigation equipment & 334511 & $\begin{array}{l}\text { Search, detection, navigation, guidance, aeronautical and } \\
\text { nautical system and instrument manufacturing }\end{array}$ & \\
\hline & \multirow{3}{*}{ Warehousing } & 493110 & General warehousing and storage & Coastal county \\
\hline & & 493120 & Refrigerated warehousing and storage & \\
\hline & & 493130 & Farm product warehousing and storage & \\
\hline
\end{tabular}


Table 2

Application of suppression rules to hypothetical data.

\begin{tabular}{|c|c|c|c|c|c|}
\hline & Establishments & Employment & & Establishments & Employment \\
\hline & \multicolumn{2}{|l|}{ Actual data } & & \multicolumn{2}{|c|}{ Actual ocean economy } \\
\hline Deep sea freight transportation & 3 & 100 & Freight transportation & 5 & 150 \\
\hline Coastal and great lakes freight transportation & 2 & 50 & & & \\
\hline Deep sea passenger transportation & 4 & 40 & Marine passenger transportation & 7 & 65 \\
\hline Coastal and great lakes passenger transportation & 3 & 25 & & & \\
\hline Port and harbor operations & 1 & 50 & Marine transportation services & 18 & 300 \\
\hline Marine cargo handling & 4 & 100 & & & \\
\hline Navigational services to shipping & 3 & 25 & & & \\
\hline Other support activities for water transportation & 10 & 125 & & & \\
\hline $\begin{array}{l}\text { Search, detection, navigation, guidance, aeronautical } \\
\text { and nautical system and instrument manufacturing }\end{array}$ & 5 & 600 & Search and navigation equipment & 5 & 600 \\
\hline General warehousing and storage & 20 & 200 & Warehousing & 35 & 335 \\
\hline Refrigerated warehousing and storage & 10 & 75 & & & \\
\hline Farm product warehousing and storage & 5 & 60 & & & \\
\hline \multirow[t]{2}{*}{ Total } & 70 & 1450 & Total & 70 & 1450 \\
\hline & \multicolumn{2}{|l|}{ Public QCEW } & & \multicolumn{2}{|c|}{ Public ocean economy } \\
\hline Deep sea freight transportation & 3 & ND & Freight transportation & ND & ND \\
\hline Coastal and great lakes freight transportation & 2 & ND & & & \\
\hline Deep sea passenger transportation & 4 & 40 & Marine passenger transportation & 7 & 65 \\
\hline Coastal and great lakes passenger transportation & 3 & 25 & & & \\
\hline Port and harbor operations & 1 & ND & Marine transportation services & ND & ND \\
\hline Marine cargo handling & 4 & 100 & & & \\
\hline Navigational services to shipping & 3 & 25 & & & \\
\hline Other support activities for water transportation & 10 & 125 & & & \\
\hline $\begin{array}{l}\text { Search, detection, navigation, guidance, aeronautical } \\
\text { and nautical system and instrument manufacturing }\end{array}$ & 5 & 600 & Search and navigation equipment & 5 & 600 \\
\hline General warehousing and storage & 20 & 200 & Warehousing & 35 & 335 \\
\hline Refrigerated warehousing and storage & 10 & 75 & & & \\
\hline Farm product warehousing and storage & 5 & 60 & & & \\
\hline Total & 70 & 1450 & Total & 70 & 1450 \\
\hline
\end{tabular}


Table 3

The US ocean economy in 2007.

\begin{tabular}{|c|c|c|c|c|c|}
\hline & Employment & Establishments & Wages (M\$) & GDP (MS) & GDP (M\$2005) \\
\hline Construction total & 99,056 & 6839 & $\$ 5704.15$ & $\$ 9902.27$ & $\$ 5778.25$ \\
\hline Marine-related construction & 99,056 & 6839 & $\$ 5704.15$ & $\$ 9902.27$ & $\$ 5778.25$ \\
\hline Living resources total & 60,977 & 6275 & \$2144.43 & $\$ 5848.97$ & $\$ 5364.09$ \\
\hline Fish hatcheries \& aquaculture & 5198 & 731 & $\$ 153.77$ & $\$ 964.80$ & $\$ 642.74$ \\
\hline Fishing & 6170 & 2228 & $\$ 384.24$ & $\$ 1325.99$ & $\$ 1277.66$ \\
\hline Seafood markets & 12,453 & 2425 & $\$ 299.33$ & $\$ 654.25$ & $\$ 680.19$ \\
\hline Seafood processing & 37,157 & 891 & $\$ 1307.08$ & $\$ 2903.93$ & $\$ 2763.50$ \\
\hline Minerals total & 144,234 & 4850 & \$17563.63 & $\$ 110441.87$ & $\$ 43255.70$ \\
\hline Oil \& gas exploration \& production & 134,151 & 4003 & $\$ 17003.12$ & $\$ 108582.73$ & $\$ 42237.49$ \\
\hline Sand \& gravel & 10,083 & 847 & $\$ 560.51$ & $\$ 1859.14$ & $\$ 1018.22$ \\
\hline Ship \& boat building total & 145,219 & 1908 & \$7072.01 & \$12851.12 & $\$ 10383.95$ \\
\hline Boat building \& repair & 47,455 & 1241 & $\$ 1815.73$ & $\$ 3803.24$ & $\$ 3073.79$ \\
\hline Ship building \& repair & 97,764 & 667 & $\$ 5256.28$ & $\$ 9047.88$ & $\$ 7310.16$ \\
\hline Tourism \& recreation total & $1,912,159$ & 113,451 & S38551.68 & $\$ 62941.70$ & \$50237.32 \\
\hline Amusement \& recreation services & 37,784 & 5643 & $\$ 762.07$ & $\$ 1136.91$ & $\$ 941.77$ \\
\hline Boat dealers & 17,430 & 2344 & $\$ 683.27$ & $\$ 1240.79$ & $\$ 1289.99$ \\
\hline Eating \& drinking places & $1,410,412$ & 88,635 & $\$ 23809.80$ & $\$ 33967.08$ & $\$ 26894.17$ \\
\hline Hotels \& lodging places & 396,099 & 11,349 & $\$ 11656.05$ & $\$ 23482.60$ & $\$ 18519.70$ \\
\hline Marinas & 18,480 & 2341 & $\$ 597.95$ & $\$ 1023.28$ & $\$ 853.23$ \\
\hline RV parks \& campgrounds & 5634 & 820 & $\$ 121.39$ & $\$ 285.93$ & $\$ 225.53$ \\
\hline Scenic water tours & 10,512 & 1572 & $\$ 273.53$ & $\$ 658.16$ & $\$ 497.26$ \\
\hline Sporting goods & 5939 & 389 & $\$ 337.06$ & $\$ 706.23$ & $\$ 685.31$ \\
\hline Zoos \& aquaria & 9871 & 358 & $\$ 310.57$ & $\$ 440.72$ & $\$ 330.36$ \\
\hline Transportation total & 320,051 & 6786 & \$22679.65 & $\$ 36098.55$ & S56934.29 \\
\hline Marine freight & 20,394 & 744 & $\$ 1855.96$ & $\$ 4531.29$ & $\$ 3380.00$ \\
\hline Marine passenger transportation & 16,441 & 274 & $\$ 810.87$ & $\$ 2207.61$ & $\$ 1647.43$ \\
\hline Marine transportation services & 94,035 & 2768 & $\$ 5839.21$ & $\$ 15544.01$ & $\$ 11744.37$ \\
\hline Search \& navigation equipment & 124,412 & 783 & $\$ 11327.69$ & $\$ 12528.92$ & $\$ 39054.28$ \\
\hline Warehousing & 64,769 & 2217 & $\$ 2845.91$ & $\$ 1286.72$ & $\$ 1108.20$ \\
\hline Ocean economy total & $2,681,695$ & 140,109 & \$93715.55 & $\$ 238084.48$ & $\$ 171953.60$ \\
\hline
\end{tabular}




\section{Table 4}

US natural resource industries (2007).

\begin{tabular}{|c|c|c|c|c|c|c|}
\hline \multirow[t]{3}{*}{ Agriculture } & & & \multicolumn{2}{|c|}{ Total } & Agriculture & Food, beverage \& \\
\hline & \multicolumn{2}{|c|}{ Employment } & \multicolumn{2}{|c|}{$2,425,000$} & 750,000 & $1,675,000$ \\
\hline & \multicolumn{2}{|c|}{ GDP $(\$ M)$} & \multicolumn{2}{|c|}{$\$ 324,657$} & $\$ 144,742$ & $\$ 179,915$ \\
\hline \multirow[t]{3}{*}{$\begin{array}{l}\text { Forest } \\
\text { products }\end{array}$} & & & \multicolumn{2}{|c|}{ Total } & $\begin{array}{l}\text { Forestry \& } \\
\text { Logging }\end{array}$ & Paper \\
\hline & \multirow{2}{*}{\multicolumn{2}{|c|}{$\begin{array}{l}\text { Employment } \\
\text { GDP (SM) }\end{array}$}} & \multicolumn{2}{|c|}{524,000} & 67,000 & 457,000 \\
\hline & & & $\$ 88,4$ & 458 & $\$ 29,848$ & $\$ 58,610$ \\
\hline \multirow{3}{*}{$\begin{array}{l}\text { Mining \& } \\
\text { metals } \\
\text { and } \\
\text { energy }\end{array}$} & & \multirow{2}{*}{\multicolumn{2}{|c|}{ Total }} & Mining & $\begin{array}{l}\text { Oil \& gas } \\
\text { extraction }\end{array}$ & $\begin{array}{l}\text { Primary Petroleum } \\
\text { metals \& coal } \\
\\
\text { manufacturing }\end{array}$ \\
\hline & & \multirow{2}{*}{\multicolumn{2}{|c|}{$\begin{array}{l}527,000 \\
\$ 413,506\end{array}$}} & 221,000 & 0146,000 & $45,000 \quad 115,000$ \\
\hline & GDP (\$M) & & & $\$ 41,893$ & $3 \$ 162,897$ & $\$ 58,991 \$ 149,725$ \\
\hline
\end{tabular}

Source: Bureau of Economic Analysis. 
Table 5

Economic performance of the ocean economy and us economy.

\begin{tabular}{|c|c|c|c|c|}
\hline & \multicolumn{2}{|l|}{$2005-2007$} & \multicolumn{2}{|l|}{$2007-2009$} \\
\hline & $\begin{array}{l}\text { Employment } \\
(\%)\end{array}$ & $\begin{array}{l}\text { Real GDP } \\
(\%)\end{array}$ & $\begin{array}{l}\text { Employment } \\
(\%)\end{array}$ & $\begin{array}{l}\text { Real GDP } \\
(\%)\end{array}$ \\
\hline Construction & 8.07 & -9.66 & -7.2 & 55.4 \\
\hline Living resources & -5.04 & 5.38 & -4.7 & -4.9 \\
\hline Minerals & 14.07 & 8.93 & -0.2 & 171.1 \\
\hline Ship \& boat building & 5.39 & 17.98 & -16.4 & -13.7 \\
\hline Tourism \& recreation & 5.36 & 6.93 & -2.6 & 4.6 \\
\hline Transportation & 5.41 & 31.45 & -5.7 & -2.4 \\
\hline Ocean economy & 3.05 & 14.43 & -3.8 & 44.9 \\
\hline U.S. economy & 2.85 & 4.62 & -4.9 & -3.8 \\
\hline
\end{tabular}




\section{Table 6}

States ranked by 2007 ocean economy employment and GDP.

\begin{tabular}{lllll}
\hline Rank & Ranked by employment & Employment & Ranked by GDP & GDP $(\$ M)$ \\
\hline 1 & California & 429,994 & Texas & $\$ 77,400$ \\
2 & Florida & 358,064 & California & $\$ 33,149$ \\
3 & New York & 324,392 & Louisiana & $\$ 25,611$ \\
4 & Texas & 177,977 & Florida & $\$ 19,937$ \\
5 & Virginia & 129,198 & New York & $\$ 18,424$ \\
6 & Washington & 111,317 & Alaska & $\$ 13,864$ \\
7 & New Jersey & 104,327 & Virginia & $\$ 6956$ \\
8 & Hawaii & 102,036 & Washington & $\$ 6919$ \\
9 & Louisiana & 95,411 & New Jersey & $\$ 6301$ \\
10 & Massachusetts & 80,791 & Hawaii & $\$ 6159$ \\
11 & Maryland & 79,969 & Illinois & $\$ 4944$ \\
12 & Illinois & 76,385 & Maryland & $\$ 4214$ \\
13 & Michigan & 73,750 & Massachusetts & $\$ 4212$ \\
14 & South Carolina & 67,876 & Michigan & $\$ 3107$ \\
15 & North Carolina & 43,246 & South Carolina & $\$ 3057$ \\
16 & Ohio & 41,569 & Connecticut & $\$ 2981$ \\
17 & Wisconsin & 39,574 & Pennsylvania & $\$ 2421$ \\
18 & Pennsylvania & 39,197 & North Carolina & $\$ 1991$ \\
19 & Connecticut & 38,945 & Mississippi & $\$ 1895$ \\
20 & Maine & 38,570 & Oregon & $\$ 1820$ \\
21 & Alaska & 36,783 & Alabama & $\$ 1795$ \\
22 & Mississippi & 32,486 & Wisconsin & $\$ 1767$ \\
23 & Rhode Island & 31,303 & Maine & $\$ 1744$ \\
24 & Oregon & 29,113 & Ohio & $\$ 1730$ \\
25 & Georgia & 24,496 & Rhode Island & $\$ 1505$ \\
26 & Alabama & 21,030 & Georgia & $\$ 1498$ \\
27 & Delaware & 17,421 & Indiana & $\$ 930$ \\
28 & Indiana & 14,168 & Minnesota & $\$ 777$ \\
29 & Minnesota & 12,542 & Delaware & $\$ 611$ \\
30 & New Hampshire & 9765 & New Hampshire & $\$ 303$ \\
\hline
\end{tabular}


Table 7

States ranked by 2007 employment and GDP normalized by coastal length.

\begin{tabular}{|c|c|c|c|c|}
\hline Rank & $\begin{array}{l}\text { Ranked by } \\
\text { employment/KM coast }\end{array}$ & $\mathrm{Emp} / \mathrm{KM}$ & $\begin{array}{l}\text { Ranked by } \\
\text { GDP/Km coast }\end{array}$ & GDP/KM \\
\hline 1 & Illinois & 688.6 & Illinois & 50.1 \\
\hline 2 & Pennsylvania & 236.4 & Texas & 37.6 \\
\hline 3 & New York & 232.0 & Massachusetts & 24.5 \\
\hline 4 & California & 221.0 & California & 19.1 \\
\hline 5 & Mississippi & 206.5 & Pennsylvania & 13.8 \\
\hline 6 & New Jersey & 181.3 & Louisiana & 13.0 \\
\hline 7 & Connecticut & 175.4 & Connecticut & 12.5 \\
\hline 8 & Florida & 163.2 & Mississippi & 11.2 \\
\hline 9 & South Carolina & 162.4 & New Jersey & 10.7 \\
\hline 10 & Indiana & 137.5 & Florida & 9.7 \\
\hline 11 & Virginia & 123.6 & Indiana & 9.4 \\
\hline 12 & Ohio & 121.4 & Alabama & 8.1 \\
\hline 13 & Rhode Island & 109.3 & South Carolina & 7.1 \\
\hline 14 & Massachusetts & 107.6 & Virginia & 6.9 \\
\hline 15 & New Hampshire & 106.6 & Rhode Island & 5.4 \\
\hline 16 & Texas & 95.7 & Maryland & 5.4 \\
\hline 17 & Alabama & 95.2 & Ohio & 4.9 \\
\hline 18 & Delaware & 86.8 & Washington & 4.6 \\
\hline 19 & Georgia & 85.7 & Georgia & 4.4 \\
\hline 20 & Maryland & 77.4 & Delaware & 3.3 \\
\hline 21 & Washington & 68.3 & Hawaii & 3.3 \\
\hline 22 & Louisiana & 63.4 & Oregon & 2.8 \\
\hline 23 & Maine & 57.6 & New York & 2.6 \\
\hline 24 & Hawaii & 57.6 & Maine & 2.6 \\
\hline 25 & Wisconsin & 41.1 & Minnesota & 2.5 \\
\hline 26 & Oregon & 39.5 & Wisconsin & 1.9 \\
\hline 27 & Minnesota & 34.5 & North Carolina & 1.2 \\
\hline 28 & North Carolina & 25.9 & Alaska & 0.7 \\
\hline 29 & Michigan & 18.3 & Michigan & 0.3 \\
\hline 30 & Alaska & 2.2 & New Hampshire & 0.2 \\
\hline
\end{tabular}




\section{Table 8}

Top 5 states in specialization in ocean economy and sectors 2007.

\begin{tabular}{|c|c|c|c|c|}
\hline Rank & Ocean economy & Construction & Living resources & Minerals \\
\hline 1 & Hawaii & Louisiana & Alaska & Alaska \\
\hline 2 & Alaska & Alaska & Mississippi & Texas \\
\hline 3 & Rhode Island & Texas & Maine & Louisiana \\
\hline 4 & Maine & Washington & Washington & Michigan \\
\hline \multirow[t]{2}{*}{5} & Louisiana & South Carolina & Massachusetts & Massachusetts \\
\hline & Ship \& Boat building & \multicolumn{2}{|c|}{ Tourism \& recreation } & Transportation \\
\hline 1 & Virginia & \multicolumn{2}{|l|}{ Hawaii } & Michigan \\
\hline 2 & Maine & \multicolumn{2}{|c|}{ Massachusetts } & Massachusetts \\
\hline 3 & Louisiana & \multicolumn{2}{|c|}{ New Hampshire } & Louisiana \\
\hline 4 & Rhode Island & \multicolumn{2}{|l|}{ Maine } & New Hampshire \\
\hline 5 & Mississippi & \multicolumn{2}{|c|}{ New York } & New York \\
\hline
\end{tabular}


Table 9

Top 5 counties by employment size and specialization in ocean economy and major sectors: 2007.

\begin{tabular}{|c|c|c|c|c|}
\hline Rank & $\begin{array}{l}\text { Ocean economy } \\
\text { Specialization }\end{array}$ & Size & $\begin{array}{l}\text { Construction } \\
\text { Specialization }\end{array}$ & Size \\
\hline 1 & Aleutians West, AK & New York, NY & Harris, TX & Harris, TX \\
\hline 2 & Bristol Bay, AK & Harris, TX & Calcasieu, LA & Calcasieu, LA \\
\hline 3 & North Slope, AK & Los Angeles, CA & Los Angeles, CA & Los Angeles, CA \\
\hline 4 & Keweenaw, MI & San Diego, CA & San Diego, CA & San Diego, CA \\
\hline 5 & Jackson, MS & Cook, IL & Hillsborough, FL & Hillsborough, FL \\
\hline \multirow[t]{2}{*}{ Rank } & Living resources & & Minerals & \\
\hline & Specialization & Size & Specialization & Size \\
\hline 1 & Aleutians West, AK & Aleutians West, AK & North Slope, AK & Harris, TX \\
\hline 2 & Bristol, MA & Bristol Bay, AK & Refugio, TX & North Slope, AK \\
\hline 3 & Essex, MA & Valdez-Cordova, AK & Iberia, LA & Terrebonne, LA \\
\hline 4 & King, WA & Pacific, WA & Terrebonne, LA & Iberia, LA \\
\hline 5 & Los Angeles, CA & Hyde, NC & Vermilion, LA & Nueces, TX \\
\hline \multirow[t]{2}{*}{ Rank } & Ship \& boat building & & Tourism \& recreation & \\
\hline & Specialization & Size & Specialization & Size \\
\hline 1 & Kitsap, WA & Portsmouth (city), VA & Keweenaw, MI & New York, NY \\
\hline 2 & Portsmouth (city), VA & Kitsap, WA & Worcester, MD & San Diego, CA \\
\hline 3 & San Diego, CA & York, ME & Monroe, FL & Cook, IL \\
\hline 4 & Jefferson, LA & Jefferson, LA & Maui, HI & Honolulu, HI \\
\hline 5 & York, ME & Mobile, AL & Mackinac, MI & San Francisco, CA \\
\hline \multirow{2}{*}{ Rank } & Transportation & & & \\
\hline & Specialization & Size & & \\
\hline 1 & Prince George, VA & Los Angeles, CA & & \\
\hline 2 & Lafourche, LA & Harris, TX & & \\
\hline 3 & Plaquemines, LA & Cook, IL & & \\
\hline 4 & Suffolk, VA & Miami-Dade, FL & & \\
\hline 5 & St. Mary, LA & Orange, $\mathrm{CA}$ & & \\
\hline
\end{tabular}

